\title{
Pengaruh Sistem Manajemen Pembelajaran Virtual Berbasis Schoology Terhadap Disposisi Matematis Siswa
}

\author{
Suradi Tahmir ${ }^{1, a)}$, Nasrullah ${ }^{1, b)}$, dan Eka Hermia ${ }^{1, c)}$ \\ ${ }^{1}$ Jurusan Matematika, Fakultas MIPA, Universitas Negeri Makassar \\ a)radita_unm@yahoo.com \\ b)nasrullah@unm.ac.id \\ c)ekahermia@gmail.com
}

\begin{abstract}
Abstrak. Penelitian ini bertujuan untuk menunjukkan pengaruh penggunaan Sistem Manajemen Pembelajaran (SMP) virtual, yaitu schoology, terhadap disposisi matematis siswa dalam pembelajaran matematika. Penelitian ini tergolong eksperimen semu (quacy experiment), yang melibatkan dua kelas yang diberikan perlakuan yang berbeda, kelas pertama yang diberikan perlakuan menggunakan sistem manajemen pembelajaran virtual menggunakan schoology dengan model pembelajaran Blended Learning dan di sebut kelas eksperimen, sedangkan kelas kedua diajarkan dengan menggunakan model pengajaran langsung dan disebut kelas kontrol. Populasi dalam penelitian adalah semua siswa kelas XI di salah satu SMA negeri di Makassar. Pengambilan sampel dalam penelitian ini menggunakan teknik purposive sampling. Untuk pengumpulan data, instrumen yang digunakan adalah angket disposisi matematis (pre-nontest dan post-nontest) dan lembar observasi keterlaksanaan pembelajaran. Data tersebut dianalisis dengan teknik statistik deskriptif dan statistik inferensial. Hasil penelitian membuktikan bahwa penggunaan sistem manajemen pembelajaran virtual berbasis schoology dengan model pembelajaran blended learning terhadap disposisi matematis lebih baik dari pada model pengajaran langsung.
\end{abstract}

Kata Kunci: SMP Virtual,Kelas Virtual, Schoology, Disposisi matematis

\begin{abstract}
This study aims to show the effect of the use of virtual Learning Management System (LMS), namely schoology, on the mathematical disposition of students in learning mathematics. This research is classified as quasi experiment, which involves two classes given different treatments, the first class is treated using a virtual learning management system using schoology with a Blended Learning learning model and called an experimental class, while the second class is taught using a model direct teaching and is called the control class. The population in this study were all students majoring in class XI in one of the state high schools in Makassar. Sampling in this study using purposive sampling technique. For data collection, the instruments used were a mathematical disposition questionnaire (pre-test and posttest) and an observation sheet of the implementation of learning. The data was analyzed with descriptive statistical techniques and inferential statistics. The results of the study prove that the virtual learning management systems based schoology with blended learning models towards mathematical dispositions is better than direct teaching models.
\end{abstract}

Keywords: Virtual SMP, Virtual Class, Schoology Mathematical Disposition 


\section{PENDAHULUAN}

Pengembangan kegiatan pembelajaran matematika di sekolah tidak hanya diarahkan pada aspek kognitif saja, tetapi juga afektif dan psikomotorik. Kemampuan afektif sangat berperan dalam meningkatkan kemampuan kognitif dan juga kemampuan psikomotorik. Oleh karena itu, perlu adanya upaya untuk meningkatkan kemampuan afektif siswa. Di dalam tujuan pembelajaran matematika pada tingkat sekolah dasar dan sekolah menengah, siswa diharapkan memiliki sikap menghargai kegunaan matematika dalam kehidupan sehari-hari, sikap rasa ingin tahu, perhatian, dan minat untuk mempelajari matematika, serta sikap ulet dan percaya diri dalam pemecahan masalah (BSNP, 2006). Siswa yang memiliki kemampuan afektif dapat dikatakan memiliki disposisi matematis.

Pentingnya disposisi dalam pembelajaran matematika adalah untuk membentuk kecenderungan secara sadar, teratur, dan sukarela berperilaku tertentu yang mengarah pada pencapaian tujuan tertentu bagi pebelajar matematika (Nasrullah, 2015). Dalam konteks matematika, disposisi matematis (mathematical disposition) berkaitan dengan bagaimana siswa memandang dan menyelesaikan masalah; apakah percaya diri, tekun, berminat, dan berpikir fleksibel untuk mengeksplorasi berbagai alternatif strategi penyelesaian masalah. Annajmi (2018) mengemukakan, disposisi matematis memberikan kontribusi sebesar $21,9 \%$ terhadap prestasi belajar matematika siswa sedangkan $78,1 \%$ dipengaruhi oleh beberapa faktor lainnya seperti kemampuan siswa dalam memahami materi pelajaran, minat, kecerdasan, kemampuan kognitif, guru dan sebagainya.

Pada kenyataannya, penelitian Kesumawati (2010) menunjukkan bahwa skor rerata disposisi matematis 297 siswa pada empat SMP di kota Palembang baru mencapai 58 persen, yang diklasifikasikan pada kategori rendah. Selain itu, penelitian Yuanari (2011) mengungkapkan bahwa siswa yang diberi angker mendapatkan skor disposisi matematis di bawah kategori baik. Rendahnya disposisi matematis diakibatkan siswa tidak mampu mengerjakan soal matematika, kurang gigih mengerjakan soal matematika, dan kurangnya keingintahuan serta rasa percaya diri siswa dalam belajar matematika (Retnowati \& Murtiyasa, 2012). Menurut Mulyana (2009) kegagalan siswa dalam mengembangkan disposisi matematikanya terjadi di sekolah menengah atas, karena mereka memiliki peluang untuk menghindari mata pelajaran matematika dengan memilih program Ilmu Pengetahuan Sosial (IPS).

Untuk mendukung tercapainya proses disposisi yang diharapkan, perlu diupayakan suatu usaha yang sungguh-sungguh dari kita semua, baik dari praktisi pendidikan matematika, dosen, guru, dan semua yang berinteraksi dengan matematika, agar kesulitan-kesulitan yang dihadapi siswa pada umumnya dapat teratasi (Jaya, 2013). Berbagi upaya harus terus dilakukan termasuk perbaikan dalam proses pembelajarannya yang salah satu diantaranya pemanfaatan teknologi yang menyajikan matematika secara virtual dan diharapkan dapat membatu meningkatkan disposisi matematis siswa.

Salah satu pemanfaatan teknologi informasi dalam bidang pendidikan adalah e-learning. Elearning merupakan sebuah inovasi yang mempunyai kontribusi sangat besar terhadap perubahan proses pembelajaran, di mana proses belajar tidak lagi hanya mendengarkan uraian materi (Adinda, 2016) . Materi bahan ajar dapat divisualisasikan dalam berbagai format dan bentuk yang lebih dinamis dan interaktif sehingga siswa akan termotivasi untuk terlibat lebih jauh dalam proses pembelajaran tersebut. Terdapat beberapa platform yang dapat digunakan sebagai media pembelajaran interaktif, salah satunya ialah Sistem Manajemen Pembelajaran (SMP).

SMP merupakan aplikasi yang berisi fitur-fitur yang dibutuhkan dalam proses pembelajaran sebagai media pembelajaran online dengan basis internet (e-learning) (Amiroh, 2013). SMP memungkinkan pelaku pendidikan masuk ke dalam ruang kelas maya untuk saling berinteraksi (berdiskusi, mengerjakan soal latihan online, dan lain-lain) serta mengakses materi-materi pembelajaran dimana saja dan kapan saja selama terkoneksi internet. 
Penelitian terkait yang dilakukan oleh Sudiana (2016) memperoleh hasil bahwa SMP mampu meningkatkan pemahaman konsep materi. Meningkatnya pemahaman konsep materi disebabkan desain SMP mempunyai tampilan yang menari dan penyajian materi yang baik.

Salah satu SMP yang dapat dimanfaatkan adalah schoology. Schoology adalah salah satu laman web yang menawarkan pembelajaran sama seperti di dalam kelas secara mudah digunakan dan gratis seperti facebook. Schoology memudahkan pelaku pendidik untuk dapat saling berinteraksi sosial maupun belajar tidak hanya terbatas hanya di dalam kelas, tetapi dapat dilanjutkan di kelas maya atau virtual class. Choirudin (2017) telah melakukan penelitian komparasi antara pembelajaran e-learning schoology dan konvensional. Hasil penelitian membuktikan keterampilan, keaktifan, hasil belajar siswa pada pembelajaran E-learning Schoology lebih baik dari pada pembelajaran konvensional.

Dari tinjauan ini, penelitian ini bertujuan mengembangkan Sistem Manajemen Pembelajaran Virtual yang mengadaptasi lingkungan pembelajaran virtual berbasis Schoology. Sistem manajemen pembelajaran virtual ini digunakan dalam kegiatan pembelajaran matematika, dan kemudian mengamati seperti apa pengaruh yang diberikan Sistem Manajemen Pembelajaran Virtual berbasis Schoology terhadap disposisi matematis siswa.

\section{KAJIAN PUSTAKA}

\section{Disposisi Matematis}

Disposisi diartikan sebagai kecenderungan dan keinginan umum mendekati dan memikirkan suatu tugas atau informasi baru dalam cara tertentu, sering kali mencerminkan pengambilan keputusan yang sadar oleh seorang pelajar (Ormrod, 2009). Sumarmo (2012) mendefinisikan disposisi matematis sebagai keinginan, kesadaran, dedikasi dan kecenderungan yang kuat pada diri siswa untuk berpikir dan berbuat secara matematik dengan cara yang positif dan didasari dengan iman, taqwa, dan ahlak mulia. Disposisi sebagai kecenderungan untuk berperilaku secara sadar (consciously), teratur (frequently), dan sukarela (voluntary) untuk mencapai tujuan tertentu. Lebih lanjut dalam konteks matematika, disposisi matematis berkaitan dengan bagaimana siswa menyelesaikan masalah matematis termasuk di dalamnya percaya diri, tekun, berminat, dan berpikir fleksibel untuk mengeksplorasi berbagai alternatif penyelesaian masalah (Mahmudi, 2010).

Untuk mengukur disposisi matematis siswa diperlukan beberapa indikator. Adapun beberapa indikator yang dinyatakan oleh National Council of Teachers of Mathematics (NCTM) (1989: 233) adalah sebagai berikut :

a. Kepercayaan diri dalam menyelesaikan masalah matematika, mengkomunikasikan ideide, dan memberi alasan.

b. Fleksibilitas dalam mengeksplorasi ide-ide matematis dan mencoba berbagai metode alternatif untuk memecahkan masalah.

c. Bertekad kuat untuk menyelesaikan tugas-tugas matematika.

d. Ketertarikan, keingintahuan, dan kemampuan untuk menemukan dalam mengerjakan matematika.

e. Kecenderungan untuk memonitor dan merefleksi proses berpikir dan kinerja diri sendiri.

f. Menilai aplikasi matematika dalam bidang lain dan dalam kehidupan sehari-hari.

g. Penghargaan (appreciation) peran matematika dalam budaya dan nilainya, baik matematika sebagai alat, maupun matematika sebagai bahasa. 


\section{Sistem Manajemen Pembelajaran}

Sistem Manajemen Pembelajaran (SMP) merupakan deskripsi dasar dari aplikasi perangkat lunak yang membantu mengotomatisasi proses administrasi dan laporan, dalam hal ini adalah dalam dunia pendidikan (Ellis, 2009). Perangkat lunak yang digunakan untuk membuat materi perkuliahan online, mengelola kegiatan pembelajaran beserta hasil-hasilnya, memfasilitasi interaksi, komunikasi, kerjasama antar pengajar dan pelajar (Sarina, 2016). SMP merupakan alat yang baik dalam melatih dan mengevaluasi suatu hasil, sehingga dapat digunakan untuk melakukan monitor terhadap pelatihan dan efektifitas dalam sebuah organisasi pendidikan (Brown \& Johnson, 2003). Secara umum SMP digunakan sebagai media untuk mengirimkan suatu fungsi dalam mengirimkan, menelusuri, melaporkan, dan mengatur isi dari materi pembelajaran, perkembangan mahasiswa dan interaksi mahasiswa (Holmes \& Gardner, 2010).

Karakteristik SMP menurut Henderson (2003) yaitu:

a. SMP membantu pengguna mengelola kompleksitas.

b. SMP akan mengelola pembelajaran secara kompleks. SMP menggunakan teknologi berbasis web yang membantu pengguna dalam hal perencanaan, pengorganisasian, implementasi, dan mengendalikan semua aspek proses pembelajaran.

c. SMP menangani tugas administrasi untuk pembelajaran elektronik (e-learning).

d. SMP menangani tugas administrasi, seperti registrasi siswa, pelacakan siswa, dan pendaftaran kelas siswa baru.

e. SMP menangani administrasi yang sangat kompleks.

f. SMP menangani administrasi pembelajaran yang sangat kompleks dengan pengaturan seratus kelas pembelajaran dan seratus murid.

g. SMP akan otomatis menangani hal, seperti katalog pembelajaran, layanan pembelajaran, pendaftaran siswa dan pelacakan, serta penilaian dan kuis.

Salah satu SMP yang bisa diterapkan dalam pembelajaran adalah Schoology (Hasanah,2011). Schoology adalah jejaring sossial berbasis web yang difokuskan pada kerjasama, untuk memungkinkan pengguna membuat, mengelola, dan saling berinteraksi serta berbagi konten akademis. Schoology juga memberikan akses pada guru dan siswa untuk presensi, pengumpulan tugas, latihan soal dan media sumber belajar yang bisa diakses kapanpun dan dimanapun serta juga memberikan akses pada orang tua untuk memantau perkembangan belajar siswa di sekolah.

Pada Schoology tersedia fasilitas Attendance atau absensi, yang digunakan untuk mengecek kehadiran siswa, serta fasilitas Analytic untuk melihat semua aktivitas siswa pada setiap course, assignment, discussion, dan aktivitas lain yang kita siapkan untuk siswa(Amiroh, 2013). Melalui schoology siswa dapat melihat pelajaran secara online, berkolaborasi dengan rekanrekan mereka dan dapat belajar secara mandiri melalui perangkat mobile mereka yang dapat dilakukan kapanpun. Schoology juga bisa diakses melalui mobile device, dengan menginstall Schoology Apps, yang bisa di download dan di gunakan secara gratis.

Penelitian terkait yang di lakukan oleh Nasrullah dan Baharman (2018) yang meneliti tentang pengaruh smp virtual terhadap kemampuan penalaran dan komunikasi siswa dalam pembelajaran matematika. Hasil penelitian penelitiaan menunjukkan bahwa skor kemampuan penalaran dan komunikasi siswa mencapai rata-rata sebesar 78,74 (maks $=95)$ dan ketuntasan secara klasikal mencapai $85 \%$. Selain itu, adanya perubahan positif terhadap kemampuan penalaran dan komunikasi dengan skor rata-rata gain sebesar 0,79 dan termasuk kategori tinggi. Dengan kata lain, SMP virtual memberikan pengaruh yang positif terhadap kemampuan penalaran dan komunikasi siswa dalam kegiatan pembelajaran matematika. Manning dan Brooks (2011) dalam penelitiannya menyimpulkan pembelajaran dengan menggunakan Schoology mampu membantu siswa dalam pembelajaran di dalam kelas. Hal ini dikarenakan media tersebut dapat digunakan untuk berinteraksi antara guru dengan siswa sehingga hal ini mampu digunakan sebagai alat untuk bekerjasama dan diskusi lebih lanjut antara siswa yang lain. Jadi dapat disimpulkan media ini mampu meningkatkan hasil belajar siswa. 


\section{METODE PENELITIAN}

Jenis penelitian yang digunakan adalah jenis penelitian quasi eksperimen. Desain penelitian dalam penelitian ini ditunjukkan pada Tabel 1 .

TABEL 1. Desain Penelitian

\begin{tabular}{cccc}
\hline Kelas & Pre-nontest & Perlakuan & Post-nontest \\
\hline Eksperimen & Y1 & X1 & Y2 \\
Kontrol & Y1 & X2 & Y2 \\
\hline
\end{tabular}

Keterangan :

Y1 : Disposisi matematis siswa sebelum diberi perlakuan

Y2 : Disposisi matematis siswa setelah diberikan perlakuan

X1 : Perlakuan menggunakan Sistem Manajemen pembelajaran berbasis schoology dengan model Blended Learning

X2 : Perlakuan menggunakan model pengajaran langsung

Penelitian ini dilaksanakan di kelas XI di salah satu SMA negeri di Makassar yang berjumlahkan 273 siswa. Dipilih dua kelas sebagai sampel berdasarkan kelengkapan fasilitas dan berdasarkan rekomendasi dari pihak sekolah dan guru bidang studi matematika. Ada dua jenis variabel dalam penelitian ini yaitu variabel bebas dan variabel terikat. Variabel bebas dalam penelitian ini adalah pembelajaran dengan perlakuan menggunakan sistem manajemen pembelajaran virtual berbasis schoology. Sedangkan variabel terikatnya adalah disposisi matematis siswa.

Teknik pengumpulan data yang dilakukan adalah pengisian angket dan pengisian lembar observasi. Instrumen yang dikembangkan yaitu angket disposisi matematis siswa dan lembar observasi keterlaksanaan pembelajaran. Instrumen telah divalidasi oleh dua ahli.

Analisis data yang digunakan pada penelitian ini yaitu analisis statistik deskriptif dan analisis statistik inferensial. Analisis statistik deskriptif digunakan untuk mendeskripsikan setiap variabel penelitian. Untuk analisis Keterlaksanaan Pembelajaran yang dilakukan dengan dua langkah yaitu menentukan frekuensi hasil pengamatan keterlaksanaan pembelajaran untuk setiap kegiatan dalam satu kali pertemuan, dan persentase keterlaksanaan pembelajaran dengan membagi besarnya frekuensi dengan jumlah frekuensi untuk semua indikator, kemudian dikalikan 100\%. Dengan kategori Keterlaksanaan Pembelajara ditunjukkan pada Tabel 2.

TABEL 2. Kategori Keterlaksanaan Pembelajaran

\begin{tabular}{cc}
\hline $\begin{array}{c}\text { Persentase Keterlaksanaan } \\
\text { Pembelajaran }\end{array}$ & Kategori \\
$\mathbf{0} \% \leq \boldsymbol{P}<\mathbf{2 0} \%$ & Kurang Sekali \\
$\mathbf{2 0} \% \leq \boldsymbol{P}<\mathbf{4 0} \%$ & Kurang \\
$\mathbf{4 0} \% \leq \boldsymbol{P}<\mathbf{6 0} \%$ & Cukup \\
$\mathbf{6 0} \% \leq \boldsymbol{P}<\mathbf{8 0} \%$ & Baik \\
$\mathbf{8 0} \% \leq \boldsymbol{P}<\mathbf{1 0 0} \%$ & Baik Sekali
\end{tabular}

Analisis statistik inferensial digunakan untuk menguji hipotesis penelitian. Namun, sebelumnya dilakukan uji prasyarat yaitu uji normalitas dan uji homogenitas. Uji normalitas yang digunakan yaitu uji Kolmogorov-smirnov. Uji homogenitas yang digunakan yaitu uji Levene's test.

Hipotesis dalam penelitian ini adalah disposisi matematis siswa yang diajar dengan menggunakan sistem manajemen pembelajaran virtual berbasis schoology dengan model pembelajaran blended learning lebih baik dari pada model pengajaran langsung. 


\section{HASIL DAN PEMBAHASAN}

Penelitian dilaksanakan dengan 4 pertemuan, pre-nontest di pertemuan pertama, dilanjutkan pembelajaran dengan menggunakan sistem manajemen pembelajaran virtual berbasis schoology dengan model pembelajaran blended learning di kelas eksperimen dan model pengajaran langsung di kelas kontrol, dan post-nontest di lakukan di pertemuan keempat setelah pembelajaran. Pre-nontest merupakan angket untuk mengukur disposisi matematis yang diberikan sebelum perlakuan. Sedangkan, post-nontest merupakan angket untuk mengukur disposisi matematis setelah perlakuan. Selain itu, selama proses pembelajaran berlangsung, dilakukan pengisian lembar observasi keterlaksanaan pembelajaran.

\section{Keterlaksanaan Pembelajaran Kelas Eksperimen}

TABEL 3. Rekapitulasi Hasil Observasi Keterlaksanaan Pembelajaran

\begin{tabular}{cc}
\hline Pertemuan & Persentase \\
\hline Pertemuan I & $100 \%$ \\
Pertemuan II & $92,3 \%$ \\
Pertemuan II & $96,15 \%$ \\
Pertemuan IV & $100 \%$ \\
Rata-Rata Total & $97,11 \%$ \\
\hline
\end{tabular}

Pada Tabel 3, secara kuantitatif menunjukkan bahwa untuk skor rata-rata semua pertemuan yaitu $97,11 \%$, berada pada interval $(80 \% \leq P<100 \%)$. Maka dapat disimpulkan secara keseluruhan observasi terhadap keterlaksanaan model pembelajaran Blended Learning dikatakan "Baik Sekali".

Berdasarkan hasil observasi pada pertemuan pertama dan pertemuan keempat semua tahap pembelajaran yang telah dilaksanakan berdasarkan RPP yang ada. Pada pertemuan kedua ada dua tahap pembelajaran yang tidak dilaksanakan yakni guru menyimpulkan kembali materi pembahasan terkait hasil diskusi kelompok dan guru memberikan pekerjaan rumah. Dan pada pertemuan ketiga ada satu tahap pembelajaran yang tidak dilaksanakan yakni guru memberikan pekerjaan rumah kepada siswa sebagai ajang latihan untuk lebih meningkatkan pemahaman siswa mengenai materi yang dijelaskan. Berdasarkan hal tersebut, maka disimpulkan bahwa proses pembelajaran yang dilaksanakan pada kelas eksperimen yang diajar dengan menggunakan model pembelajaran Blended Learning telah terlaksana sesuai dengan RPP yang ada.

\section{Keterlaksanaan Pembelajaran Kelas Kontrol}

TABEL 4. Rekapitulasi Hasil Observasi Keterlaksanaan Pembelajaran

\begin{tabular}{cc}
\hline Pertemuan & Persentase \\
\hline Pertemuan I & $100 \%$ \\
Pertemuan II & $85,7 \%$ \\
Pertemuan II & $85,7 \%$ \\
Pertemuan IV & $85,7 \%$ \\
Rata-Rata Total & $90,75 \%$ \\
\hline
\end{tabular}

Pada Tabel 4, secara kuantitatif menunjukkan bahwa untuk skor rata-rata semua pertemuan yaitu $90,75 \%$ dan berada pada interval $(80 \% \leq P<100 \%)$. Maka dapat disimpulkan secara keseluruhan observasi terhadap keterlaksanaan model Pengajaran Langsung dikatakan "Baik Sekali”.

Berdasarkan hasil observasi pada pertemuan pertama semua tahap pembelajaran yang telah dilaksanakan berdasarkan RPP yang ada. Pada pertemuan kedua dan ketiga ada dua tahap pembelajaran yang tidak dilaksanakan guru bersama-sama dengan siswa membuat 
rangkuman/simpulan materi yang telah dipelajari dan memberikan pekerjaan rumah (PR) kepada siswa yang diambil dari Tugas Mandiri pada buku siswa. Dan pada pertemuan ke-empat ada satu tahap pembelajaran yang tidak dilaksanakan yakni guru bersama-sama dengan siswa membuat rangkuman/ simpulan materi yang telah dipelajari. Berdasarkan hal tersebut, maka disimpulkan bahwa proses pembelajaran yang dilaksanakan pada kelas kontrol yang diajar dengan menggunakan model pengajaran langsung telah terlaksana sesuai dengan RPP yang ada.

\section{Disposisi Matematis}

\section{Analisis Deskriptif}

Data yang diperoleh dalam penelitian ini adalah data tentang disposisi matematis siswa. Disposisi matematis siswa yang diajarkan dengan penerapan sistem manajemen pembelajaran virtual menggunakan schoology dengan model Blended Learning dan penerapan model pengajaran langsung. Data dideskripsikan berdasarkan analisis data pre-nontest dan postnontest.

TABEL 5. Rekapitulasi Nilai Kelas Eksperimen

\begin{tabular}{ccc}
\hline \multirow{2}{*}{ Statistik } & \multicolumn{2}{c}{ Nilai } \\
\cline { 2 - 3 } & Pre-nontest & Post-nontest \\
Range & 36 & 44.00 \\
Nilai Terendah & 81 & 105 \\
Nilai Tertinggi & 117 & 149 \\
Nilai Rata-rata & 100.29 & 123.88 \\
Variansi & 72.941 & 122.96 \\
\hline
\end{tabular}

Pada Tabel 5 menunjukkan bahwa disposisi matematis siswa mengalami peningkatan dilihat dari nilai tertinggi siswa sebelum perlakuan 117 menjadi 149 dari skor maksimal 160. Selain itu peningkatan disposisi matematis siswa dapat dilihat dari peningkatan skor rata-rata sebesar 23.59 dari skor rata-rata awal 100.29 menjadi 123.88 .

TABEL 6. Klasifikasi gain ternormalisasi kelas eksperimen

\begin{tabular}{cccc}
\hline Nilai siswa & Kategori & Frekuensi & Persentase (\%) \\
\hline$g>0,70$ & Tinggi & 1 & $2,9 \%$ \\
$0,30 \leq g \leq 0,70$ & Sedang & 21 & $61,8 \%$ \\
$g \leq 0,30$ & Rendah & 12 & $35,3 \%$ \\
\hline Jumlah & & 34 & $100 \%$ \\
\hline
\end{tabular}

Pada Tabel 6 peningkatan disposisi matematis siswa di kelas eksperimen sebagian besar berada pada kategori sedang yaitu sebanyak $61.8 \%$ siswa. Sedangkan, $35.3 \%$ siswa berada dalam kateori rendah. Dapat disimpulkan bahwa disposisi matematis siswa yang diajar sistem manajemen pembelajaran virtual menggunakan schoology dengan model Blended Learning berada pada kategori sedang.

\section{Analisis Inferensial}

Pada analisis inferensial, berdasarkan uji normalitas untuk hasil pre-nontest dan post-nontest disposisi matematis siswa diperoleh $p$-value $>\alpha$ yaitu $0,200>0,05$. Hal ini menunjukkan bahwa data hasil pre-nontest dan post-nontest disposisi matematis siswa berasal dari populasi yang berdistribusi normal. Berdasarkan uji homogenitas untuk kedua kelas, hasil analisis menggunakan uji Levene's, dihasilkan p-value dari data disposisi matematis siswa adalah 0,983. Nilai $p$-value tersebut lebih besar dari $\alpha(0,983>0,05)$, sehingga dapat disimpulkan bahwa data dari kedua kelompok adalah sama. 
TABEL 7. Hasil Perhitungan Uji Hipotesis

\begin{tabular}{cccc}
\hline Variabel & Nilai t & Signifikan & Nilai $\boldsymbol{\alpha}$ \\
\hline $\begin{array}{c}\text { Disposisi Matematis } \\
\text { (post-nontest) }\end{array}$ & 5.552 & .000 & 0.05 \\
\hline
\end{tabular}

Berdasarkan Tabel 7 diperoleh nilai sig. (2-tailed) sebesar $0.000<0.05$ dan dan nilai ( $\mathrm{t}$ hitung) 5.552>1.670 (t-tabel). Maka secara statistik hipotesis $\mathrm{H}_{0}$ ditolak atau $\mathrm{H}_{1}$ diterima. Jadi disimpulkan bahwa disposisi matematis siswa yang diajar dengan menggunakan sistem manajemen pembelajaran virtual berbasis schoology dengan model pembelajaran blended learning lebih baik dari pada model pengajaran langsung.

Hasil ini sejalan dengan pendapat yang mengemukakan pembelajaran dengan menggunakan Schoology mampu membantu siswa dalam pembelajaran di dalam kelas, dikarenakan media tersebut dapat digunakan untuk berinteraksi antara guru dengan siswa sehingga hal ini mampu digunakan sebagai alat untuk bekerjasama dan diskusi lebih lanjut antara siswa yang lain (Carmen \& William, 2011). Penerapan media schoology dapat meningkatkan aktivitas siswa dan hasil belajar (Aminoto \& Pathoni, 2014).

\section{KESIMPULAN}

Penelitian ini bertujuan untuk mengetahui seperti apa pengaruh yang diberikan Sistem Manajemen Pembelajaran Virtual berbasis Schoology terhadap disposisi matematis siswa. Kesimpulan yang diperoleh bahwa penggunaan sistem manajemen pembelajaran virtual berbasis schoology dengan model pembelajaran blended learning terhadap disposisi matematis lebih baik dari pada model pengajaran langsung.

Penelitian ini hanya berfokus terhadap disposisi matematis saja. Sehingga diharapkan adanya penelitian yang mengukur pengaruh Sistem Manajemen Pembelajaran Virtual berbasis schoology terhadap aspek lain, contohnya pengaruh terhadap hasil belajar, kemampuan komunikasi matematis siswa dan prestasi belajar. Selain itu penggunaan Sistem Manajemen Pembelajaran Virtual berbasis schoology tidak hanya dapat digunakan pada materi matrik, sistem ini dapat juga di terapkan pada materi matematika yang lain

\section{DAFTAR PUSTAKA}

Adinda, W. A. (2016). Pengembangan E-Learning Dengan Schoology Sebagai Suplemen Pembelajaran Fisika Pada Materi Usaha Dan Energi. (Skripsi).Universitas Lampung, Lampung

Aminoto, T., \& Pathoni, H. (2014). Penerapan Media E-Learning Berbasis Schoology untuk Meningkatkan Aktivitas dan Hasil Belajar Materi Usaha dan Energi di Kelas XI SMA N 10 Kota Jambi. Jurnal Pendidikan Fisika, 8(1). 14-29

Amiroh. (2012). Under E-Learning, Edmodo, Moodle and Schoology. [online]. http://amiroh.web.id. Diakses pada tanggal 21 Maret 2019

Annajmi. (2018). Kontribusi Disposisi Matematis terhadap Prestasi Belajar Matematika Siswa Kelas VIII SMPN 3 Tambusai. Jurnal Pendidikan Matematika, 8(1).

Brown, A. \& Johnson, J. (2003). Five Advantages of Using a Learning Management System. [online]. www.microburstlearning.com. Diakses pada tanggal 30 Januari 2019

BSNP. (2006). Standar Kompetensi dan Kompetensi Dasar SMP/MTs. Jakarta: Balitbang.

Carmen, M. \& William, B. (2011). Teach Tools For Teachers, By Teachers: Bridging Teachers and Students. Wisconsin English Journal, 53(1).

Choirudin. (2017). Efektivitas Pembelajaran Berbasis Schoology. Numerical: Jurnal Matematika dan Pendidikan Matematika, 1(2). 
Ellis, R. K. (2009). Field Guide to Learning Management Systems. [online]. http://www.astd.org/NR/rdonlyres/12ECDB99-3B91-403E-9B15-7E597444645D/233 95/LMS fieldguide 20091.pdf. Diakses pada tanggal 1 Januari 2019

Hasana, N. (2016). Pengembangan E-Learning Dengan Schoology Sebagai Suplemen Pembelajaran Fisika Pada Materi Elastisitas Dan Hukum Hooke. (Skripsi). Universitas Lampung, Bandar Lampung

Henderson, J. A. (2003). The E-Learning Question and Answer Book. New York: American Management Association.

Holmes, B., \& Gardner, J.R. (2006). E-Learning: Concepts and Practice. London: Sage Publications Ltd

Jaya, A. (2013). Pengaruh Penerapan Blended E-Learning Berbasis Website Terhadap Peningkatan Kemampuan Pemahaman Dan Berpikir Logis Matematis Siswa Sma. (Thesis). Universitas Pendidikan Indonesia, Bandung

Kesumawati, N. (2010). Asosiasi Kemampuan Pemahaman dan Disposisi Matematis. Jurnal Pendidikan MIPA FKIP UNILA. 11.

Mahmudi, A. (2010). Tinjauan Asosiasi antara Kemampuan Pemecahan Masalah Matematis dan Disposisi Matematis. Seminar Nasional Pendidikan Matematika FMIPA UNY, 17.

Manning., \& Brooks. (2011). A tech tools for teachers, by teachers: Bridging teachers and students. Wisconsin English Journal, 53(1). 24-28.

Mulyana, E.(2009). Pengaruh Model Pembelajaran Matematika Knisley Terhadap Peningkatan Pemahaman dan Disposisi Matematika Siswa SMA Program IPA. (Disertasi). UPI, Bandung.

Nasrullah. (2015). Pengaruh Model PMK Terhadap Disposisi Matematis dalam Pembelajaran Matematika Tingkat SMA. Jurnal Matematika Kreatif-Inovasi: Kreano, 6 (1). 12-20

Nasrullah., \& Baharman. (2017). Pengaruh SMP Virtual terhadap Kemampuan Penalaran dan Komunikasi Siswa dalam Pembelajaran Matematika. Seminar Nasional Lembaga Penelitian UNM, 2(1).

NCTM. (1989). Curriculum and Evaluation Standards for School Mathematics. Reston, VA: NCTM

Ormrod, E. J. (2009). Psikologi pendidikan membantu siswa tumbuh dan berkembang Edisi keenam jilid 1. Jakarta: Erlangga

Retnowati, D., \& Murtiyasa, B. (2013). Upaya Meningkatkan Pemahaman Konsep dan Disposisi Matematis Menggunakan Model Pembelajaran Treffinger. Seminar Nasional Pendidikan Matematika FKIP UMS. 14-23

Sarina, A. (2016). Pengelolaan Learning Management Sysytem (LMS) Sebagai Media Pembelajaran Di Universitas Hasanuddin. (Skripsi). Universitas Hasanuddin, Makassar

Sudiana, R. (2016). Efektifitas Penggunaan Learning Management System Berbasis Online. Jurnal Penelitian dan Pembelajaran Matematika, 9(2).

Sumarmo, U. (2012). Pendidikan Karakter serta Pengembangan Berpikir dan disposisi Matematik dalam Pembelajaran Matematika. Seminar Pendidikan Matematika. 126.

Yuanari, N. (2011). Penerapan Strategi Think-Talk-Write sebagai Upaya Meningkatkan Kemampuan Pemecahan Masalah dan Disposisi Matematis Siswa Kelas VII SMPN 5 Wates Kulonprogo. (Thesis). Universitas Negeri Yogyakarta, Yogyakarta 